\title{
Semantic shifts of sublanguage units
}

\author{
Olga Nikolenko ${ }^{1, *}$, Yulia Drozdova $^{1}$ and Larisa Lepihova ${ }^{1}$ \\ ${ }^{1}$ Don State Technical University, 1, Gagarin sq., 344003, Rostov-on-Don, Russia
}

\begin{abstract}
The article considers slang as an ideological sign and a sublanguage unit capable of expanding its meaning due to semantic refraction, and also proposes a structural and semantic description of slangisms and proves the idea that they, as a means of metaphorizing a language, endow the utterance with additional meaningful veils, not only affecting its information filling and imagery, but also reflecting the author's individuality, contribute to its emotional and expressive enrichment while maintaining the basic conceptual center, albeit semantically blurred. Observation shows: the more perceptible the semantic bi-planarity of the sublanguage, the more informative the syntaxeme that includes it, respectively, during the functioning of slangism, expressive informativeness is embodied in semantic and emotional increments that affect both the rational-logical and expressive-figurative content of the context. However, regardless of the contextual conditions, the preponderance in the meaning of the described units is always on the side of the expressive-emotional components, accompanied by linguistic veils, focused on pragmatic impact, since it contains an internal suggestive force directed at the communicant. Speech influence in the indicated constructions is performed through the formation and transmission of the author's "I", which makes it possible for the "creator of the text" to reveal the nuances of the meanings of dependent elements and, through a variant change in their positions, expand the boundaries of the subtext. This makes the sublanguage a convenient verbal form of ideology expression, representing the worldview of a person, regulating his upbringing, forming habits, orienting social behavior and reflecting the volume of cultural memory.
\end{abstract}

\section{Introduction}

Modern linguistic science increasingly tends to study the way of reflection in the language of reality, which contributes to the shift of research interest towards to the description of cognitive processes in communication. This is done in such areas as psycholinguistics, suggestive linguistics, expressive syntax, linguistic pragmatics, theory of mass communication, conflict management, etc. The object of study of these sciences is speech impact as a way of effective communication. In other words, in society, it becomes necessary to consider language not only as a tool for understanding the world, transmitting information about it, but also as a means of influencing the consciousness of a particular person, a means of representing his worldview, a form of habit creation and social behavior. In this regard, the relevance of the proposed work is due to the need for an extended analysis of sublanguage

\footnotetext{
* Corresponding author: olganikolenko15011977@gmail.com
} 
lexemes in order to determine their suggestive status, the ability to concretize the meaningful plan of the phrase, to whip up expressiveness, emotionality and personally label the phrase; therefore, the feasibility of considering the mentioned lexemes in the indicated key is justified by the fact that they act as an auxiliary code for extracting an information segment from the speech stream and reinforcing suggestion.

\section{Materials and methods}

The linguistic materials for writing this study were examples from journalism, materials from television programs, as well as, to a small extent, from prose works of fiction. The work is carried out in direction with the general philosophical methodological concept, which is that cognitive factors are brought to the fore, assuming that the suggestive capabilities of the language are taken into account as initial attitudes. The research was conducted by direct observation of the language facts, in this regard, the method of positive and negative experiments is applied; reception of statistical calculation, as well as transformational analysis, transformation and substitution is also used.

\section{Results}

As is well known, our language is a reflection of reality: it captures and conveys all the processes taking place in society, that is why it is justly called the mirror of the era.

Naturally, each time period is characterized by its own "set" of lexico-semantic, structural and semantic features: new words appear, lexemes "unclaimed" by society become the past, old ones are rethought, narrowing or expanding their meaning. Linguists have to state the fact that in modern society there has been a speech shift towards to uncodified units: the sublanguage is increasingly invading the literary language, which erases the boundaries between the norm and its violation [1].

We consider that semantic "metamorphoses" are primarily connected with the desire of a particular person to get away from impersonalization (including linguistic), "designate" their individuality, leave a communicative aftertaste and, of course, prioritize the self-position, influencing the mind and feelings of the interlocutor.

All this suggests that language serves, among other things, as a form of manifestation of a certain ideology, through the prism of which we interpret reality, fix our location in this reality and project ourselves outward [2].The need for orientation in the surrounding reality forces an individual to choose from a multitude of verbal signs that he encounters and which refracts through subjectivity, those that are considered spiritually significant for him, i.e. constitute his ideology, represent his worldview, regulate upbringing, form habits, orient social behavior and reflect the volume of cultural memory [3].

A correctly chosen conceptual structural-semantic language system is a mirror that forms a speech portrait of a particular era and a particular personality in it [4].

Let's give examples and prove that even a unit of a sublanguage, which is stylistically appropriate, expands the semantic boundaries of a phrase:

И все те, кто ворует, киркой сами не вкалывают.

(A. Solzhenitsyn. One day of Ivan Denisovich).

Но он не мог быть особенным и вкалывал наряду со всеми.

(Russian newspaper. No. 254)

Let's pay attention to the word worked «вкалывал». In the Explanatory Dictionary edited by Efremova, we find two interpretations of it: 1. Punctured, to introduce deep into something, to insert something pointed, subtle. 2. Work hard and hard. 
Even without delving into the etymology of the figurative meaning of this lexeme, we see that in the semantic respect it is a multi-layered semantic unit: in addition to the pictorial shell with an explicit meaning, semantically refracting, it contains informational subtext with implicit emotional and expressive expression [5], which makes it possible to record a much larger amount of information in it than in neutral versions.

Compare: И все те, кто ворует, киркой сами много и напряжённо не работают.

Но он не мог быть особенным и много и напряжённо работал наряду со всеми.

We see that when replacing slangism "вкалывать" with its stylistically neutral descriptive synonym from the entire syntaxeme is removed not only emotionality, conveying the author's position in relation to the situation, but also erases the semantic veil [6], which endows the phrase with an ideological secret and contributes to the achievement of pragmatic goals in the process of communication.

Moreover, it seems that the implicit meaning of the sublanguage fixes the peculiarities of a particular social or age group mentality, shows the system of its values, gives a characteristic, and also implants a moral ideal through suggestion:

Consider the phrase: Я вижу, что друг твой-отъявленный беспредельщик.

This sentence proves: contrary to grammatical laws, which assert that adjectives give a better description of an object or phenomenon, emotionally colored units are not inferior to lexemes - definitions in terms of the power of informative and semantic implementation. Here we mean the word "беспредельщик" a person (what?) who does not know the limit, the boundaries of what is permitted.

Slangism "отъявленный", endowed with a sharply dismissive expression, has the meaning of "неисправимый", probably cut off from reality (reality, truth), descended into darkness, and took the side of evil. Hence the "rigid" framework in the contextual implementation: it is used only with animate nouns that have a negative meaning: a notorious villain, a cheater, a drunkard, an outlaw, etc. Structurally joining, these two words form a phraseologically related unit, which (unlike a single word)characterized by a large proportion of connotative elements that express the speaker's subjective attitude to the world of objective phenomena. This means that sublanguage units, due to the semantic veil that gives the word the ability to move from an external stimulating factor to an internal one, can convey expression, emotions, a complex range of relations to reality, to the interlocutor, to the subject of speech, etc., thereby performing a pragmatic function.

The presence of certain pragmatic meanings in a syntaxeme is determined by the nature of the figurative basis of its constituent lexemes, stylistic characteristics, as well as semantic accessibility, implying its recognition and detection in an extended meaning by all participants in communication.

Trying to be realized in the communicative plan, a person often introduces sublanguage and semantically rethought words into his speech [8] in order not only to seem original to the interlocutor, but also to find a common language with him, to get one level of communication.

Slangism as one of the types of sublanguage and semantically rethought units with a capacious informational and pragmatic content is endowed with an expressive communicative form [7], since it is always metaphorical. This metaphor is based on the speaker's desire to influence the listener in a certain way.

For example: Вчера я перерыл весь Интернет, чтобы выполнить твою просьбу.

In the sentence, with the word "перерыл", which has an informational connotation, the author tries to convince his recipient in the difficulty and duration of the actions he performed (which is facilitated by the grammatical indicator - the prefix -пере). If you make a semantic analysis of the verb "рыть", then you can see that in its direct meaning it makes sense to "копать землю" in order to find something hidden in it and extract from it, in contrast to "копать" - to dig.

Compare: Я перерыл всю землю в саду (He was looking for something); 
Я перекопал всю землю в саду (He digged the land).

On the other hand, due to its grammatical capabilities, the verb "копать" with the prefix "-на" can expand its direct meaning and be used in a slang context:

Я многое накопал на него!

In its direct meaning, management with the preposition "-на" is not typical for the verb "накопал", since it has a subjective and objective meaning.

Compare: Я накопал (что) червей для рыбалки (для чего).

As you can see, it is in the extended structural and semantic embodiment that words have an internal process of adding meanings, which fills the phrase with a new emotional and expressive meaning, focusing attention on the most key points of the utterance and conveying much more information than synonymous neutral constructions.

In the semantic embodiment "накопал-нашел, обнаружил" due to the preposition "-на" expands with a semantic sprout, which renews the internal content, and that is contributes to the emotional and expressive enrichment of the phrase while maintaining the basic conceptual center.

In addition, preferring the lexeme «накопал» to the word «нашел» in the context «накопал информацию», the speaker in the process of communication uses a speech product with semantic (meaning «открыл») and grammatical ( prefix «-на» meaningfully directs the action to the surface of the subject, introducing adverbial meaning, synonymous with the addition with the preposition "o") borrowing a literary unit.

Such observation for the properties of the sublanguage suggests that a semantic shift occurs in such lexemes due to a change in the content while maintaining the external form [9].

Due to the derivation of meaning, correctly "born" and appropriately used sublanguage units not only do not clog the language, but also contribute to its metaphorization, since they interpret the linguistic picture of a particular society and serve as a means of situational communication [10], at the same time forming an individual "speech handwriting" of a particular person, endow a bright shell to his ideological position [11], which is able to convey semantically updated information to its addressee and make him catch meaningful veils, since vocabulary subjected to semantic derivation, with its background meaning, involves the field of emotions, assessments, and expression.

Here are some more examples:

В школе мрак! Следи за своим базаром!

Expanding in meanings, the words "мрак" and "базар" in such slang phrases perform an expressive-evaluative function, since they are metaphors-characteristics with evaluative meanings that rename already existing concepts in an associative way ("мрак" is the absence of light (direct meaning); "мрак" - no clarity (figurative meaning)).

Naturally, the slang unit should be situational and stylistically appropriate, i.e. directed at the addressee and the situation where just such a linguistic expression is close, because in order to grasp the content of the text, you need to know much more than the meanings of its constituent words, because they are only signals of meaning, the condition for adequate perception of which is background knowledge [12], that increases additional shades and set an informal, emotionally colored tone of the narrative, contributes to the conduct of a casual conversation, which forms the basis for the appropriate expression of speech intentions by the speaker [13].

\section{Discussion}

Numerous works of linguists (Babushkina A.P., Barannikova L.I., Beglova E.I., Beregovskaya, Bobakho V.A., etc.) are devoted to the solution of a number of acutely debated problems arising in connection with the multifunctionality of the sublanguage. The 
aforementioned linguists, developing thoughts about the suggestive nature of language, prove that any unit of it is capable of transmitting both direct information and the author's marked subtext. Naturally, the suggestive capabilities of different units are not the same. We believe that the sublanguage is endowed with a large influencing charge. It is the sublanguage, according to Boyko B.Ya., Boldareva E.F., Gorbachevich K.S., Grachev M.A., Ermakova O.P., Zhuravlev V.K. and others initiate cognitive operations that carry evaluative information [14], capable toreconstruct the image of reality and create attitudes for its comprehension in a new perspective. The works of these scientists characterize the sublanguage in many aspects, in the variety of its manifestations [15], however, there is no detailed description of each level for its concrete contribution to the named cognitive area.

\section{Conclusions}

As you can see, sublanguage units, functioning both in oral and written speech, serve (among other things) as a kind of suggestive element that makes the addressee perceive the phrase figuratively, given its subtext semantics. It is this feature of the designated lexemes that makes them the most frequently used units in the speech of representatives of different generations. With the help of the sublanguage, communicants can build personally marked syntaxemes, evaluate an extra-linguistic situation, enter an internal discussion, intensify expression, form the desired emotional mood [16], prompting the recipient to discover the hidden meaning of the phrase, remove the semantic veils. Certainly, the more accurately the metaphorical transfer is carried out, the higher the possibility that the addressee will be able to put the necessary thought into the mind of his interlocutor with the help of an image and associative concomitant meanings, gently directing the recipient's notion to the required setting.

\section{References}

1. E.M. Beregovskaya, Questions of linguistics 3, 32-41 (1996)

2. V.A. Bobaho, Social Sciences and Modernity 3, 56-60 (1996)

3. E.F. Boldareva, Language game as a form of emotion expression: author. dis. ... Cand. philol. sciences (Volgograd, 2002)

4. M.A. Glukhova, Metaphorization in argot: author. dis. ... Cand. philol. Sciences (Tver, 2003)

5. M.A. Grachev, Russian speech 5, 67-73 (2001)

6. E.V. Klepach, Linguistic fashion: evolution of linguocultural forms: author. dis. Cand. Phil. nauk (M., 2000)

7. V.G. Kostomarov, Language taste of the era: from observations of the speech practice of the mass media (Zlatoust, $\mathrm{SPb}, 1999)$

8. Yu.Z. Crassa, S.I. Argot, Phraseological units in modern Russian: semantic and linguocultural aspects: author. dis. ... Cand. philol. sciences (Stavropol, 2000)

9. Yu.O. Nesterova, Language game in modern Russian colloquial speech: author. dis. Cand. philol. sciences (Vladivostok, 2001)

10. O.V. Nikolenko, International scientific-practical conference "Axiological linguistic methods: worldview and value aspects in school and university teaching of the Russian language" (Moscow State Pedagogical University, Institute of Philology, 2019) 
11. O.V. Nikolenko, Interuniversity collection of scientific papers with international participation "Semantics. Functioning. Text. On the occasion of the 70th birthday of S.V. Rough" (Kirov: LLC "Publishing house" Raduga-EXPRESS ", 2018)

12. O.V. Nikolenko et al, The 9-th International Scientific and Practical Conference "Current issues of linguistics and didactics: The interdisciplinary approach in humanities" SHS Web of Conferences 69, $00081 \quad$ (2019) https://doi.org/10.1051/shsconf/20196900081

13. O.V. Nikolenko, N.V. Sumina, A.V. Belozerova, E.Yu. Shapovalova, IOP Conference Series: Materials Science and Engineering 483 (2019) https://iopscience.iop.org/article/10.1088/1757899X/483/1/012106/pdf

14. E.I. Khan-Pira, Banner 7, 231-234 (1998)

15. J.K. Androutsopoulos, Deutsche Jugendsprache. Untersuchungen zu ihren Strukturen und Funktionen (Lang, F.a.M., 1998)

16. P.M. Wittenberg, Federal Probation 60(4), 45-51 (1996) 